\title{
Editorial: The Mauritius Convention on Transparency
}

\section{A Piece of Constitutional Reform of the International Investment Regime}

In the midst of heated debates on investor-State dispute settlement in Europe, on 10 December 2014 the United Nations General Assembly adopted the United Nations Convention on Transparency in Treaty-based Investor-State Arbitration. ${ }^{1}$ Prepared by UNCITRAL in the context of its recent revision of the UNCITRAL Arbitration Rules, the Convention, also known as the 'Mauritius Convention on Transparency', was opened for signature on 17 March 2015 in Port Louis, Mauritius. It will extend the application of the UNCITRAL Rules on Transparency, which so far have a very limited scope of application (only to UNCITRAL investor-State arbitrations that are based on treaties concluded on or after 1 April 2014), ${ }^{2}$ potentially to the entire treaty-based international investment regime as it stood on 1 April 2014.

Notably, the Mauritius Convention would make the UNCITRALTransparency Rules applicable to all treaty-based investor-State arbitrations under 'old' treaties, independently of the applicable arbitration rules. Whether the arbitration in question is governed by the UNCITRAL Arbitration Rules, the ICSID Convention, the Arbitration Rules of the International Chamber of Commerce, the Arbitration Rules of the Arbitration Institute of the Stockholm Chamber of Commerce - you name it - the Mauritius Convention would provide for transparency of submissions to arbitral tribunals, arbitration hearings, and

1 United Nations General Assembly, Resolution 69/116 (10 December 2014), UN Doc No A/Res/69/116 (18 December 2014).

2 See Article 1(2) of the UNCITRAL Rules on Transparency, available in United Nations, 'Report of the United Nations Commission on International Trade Law of its Forty-sixth Session (8-26 July 2013)' Official Records of the General Assembly, Sixty-eighth Session, Supplement No ${ }_{17}(\mathrm{~A} / 68 / 17)(2013)$ AnnexI <http://www.un.org/en/ga/search/view_doc.asp?symbol=A/68/17> accessed 24 February 2015. Examples of treaties that make reference to the new Transparency Rules are the Switzerland-Georgia BIT of 3 June 2014 or the EU-Canada Comprehensive Trade and Economic Agreement (CETA), article X.33. 
decisions by arbitral tribunals, and give more room for third-party participation under a uniform set of rules. It could apply to some 3000+ investment treaty relations if both the respondent State and the investor's home State are contracting parties or, alternatively, if the investor-claimant accepts the unilateral offer to apply the UNCITRAL Transparency Rules made by the respondent in signing the Convention (see Article 2 of the Mauritius Convention).

Provided it is signed and ratified by a sufficiently large number of States and regional economic integration organizations, such as the EU or ASEAN, the Mauritius Convention will bring about a paradigm shift in investor-State dispute settlement. Although possibilities for reservations, including subsequent ones, are broad (Articles 3 and 4 of the Mauritius Convention), and although ongoing arbitrations are excluded from its scope of application (Article 5 of the Mauritius Convention), the Convention will establish transparency as a general principle of international investment law. This constitutes another step in the incremental adaptation of international investment law to the demands of a more democratic and accountable international public law system of private-public adjudication. The wide-spread application of transparency under the Convention would not only enhance the accountability of the underlying investor-State relations, but also enable better public control of the arbitral process. This turns the Mauritius Convention into an instrument with constitutional implications for the international investment regime.

\section{A Model for Investment Law Reform?}

Apart from its contribution to enhancing the legitimacy of international investment law and investor-State dispute settlement, the Mauritius Convention also provides an interesting example for how the existing international investment regime can be reformed multilaterally through an incremental opt-in approach. While many comprehensive multilateral reforms are slow to progress, the Mauritius Convention has relatively quickly resulted in a consented text by focusing on a clearly defined and narrow, but no less important issue. Its exclusive focus on a single issue (transparency and third-party participation) prevented cross-deals with other issues on the reform agenda and helped to streamline negotiations.

Notwithstanding its narrow focus, the Mauritius Convention pursues a systematic reform approach and confronts the fragmented structure of the international investment regime by proposing a legal principle (transparency) that applies to all existing bilateral, regional, and multilateral investment treaties, and in all available arbitral fora. Sensibly, the Convention also clarifies that the 
Transparency Rules cannot be circumvented through the application of mostfavored-nation clauses (Article 1(5)). Yet, flexibility is introduced through possibilities for reservations. In addition, the Convention only has a retroactive scope of application, leaving open what States will do in future treaties. Nonetheless, by laying down transparency as a principle of investor-State dispute settlement, the Mauritius Convention will exercise a considerable normative pull in the ongoing reform efforts. After all, going back to a lower level of transparency will be difficult in light of already wary publics in many democratic societies as regards the topic of investor-State dispute settlement.

The 'Mauritius approach' to investment treaty reform responds to the difficulties a piecemeal, treaty-by-treaty approach to investment law reform entails in light of the decentralized nature of investment law and investor-State dispute settlement. After all, advances in a single bilateral treaty could be easily circumvented either through the operation of most-favored-nation clauses or nationality planning. In this sense, the Mauritius approach may become a model for how certain issues of international investment law can be reformed multilaterally without the need to enter into comprehensive multilateral negotiations. This approach will not lend itself to the reform of every single of the many contentious issues, in particular not to the isolated reform of specific substantive investment protection standards; but it may work for taking care of other systemic matters that can be dealt with independently of substantive protection standards, such as introducing corporate social responsibility or creating an appeals facility for investment treaty awards.

\section{Evolution, Not Revolution}

The Mauritius Convention is not a revolutionary development. It builds on the incremental emergence of transparency in earlier investment treaties and the reform of the UNCITRAL Arbitration Rules - and its adoption is in the hands of States. But its normative pull and its transformative effect should not be underestimated. It is a component of a new system of international investment law that is fundamentally different from the current one, which is still principally based on confidentiality. The Mauritius Convention further underscores investment law's public law nature and breaks with the so far still dominant conceptualization of investor-State dispute settlement as a form of commercial arbitration and private justice.

What will be crucial now is to get States and supranational organizations to sign and ratify the Convention. Emphasizing the benefits of transparency for good governance and an overall better, more accountable, and more democratic international investment regime will be key. Governments and international 
organizations that support transparency should play an active role in lobbying for the wide-spread adoption of the Mauritius Convention among those States who are still hesitant. What is at stake, in case the Mauritius Convention finds insufficient support, is no less than a further jolt to an already trembling investment law system.

Stephan W. Schill 